Lawrence Livermore National Laboratory

University of California, Livermore, California 94550

UCRL-ID-150435

\title{
Final ROI Report - Technology Transfer of Waste-Reducing Groundwater Sampling Systems
}

\section{Authors}

Charles Noyes ${ }^{1}$

Greg Howard ${ }^{1}$

Dorothy Bishop ${ }^{1}$

Cary Tuckfield ${ }^{2}$

Robert Hiergesell ${ }^{2}$

September 30, 2002

1 LLNL, Livermore, CA

${ }^{2}$ SRS, Aiken, SC

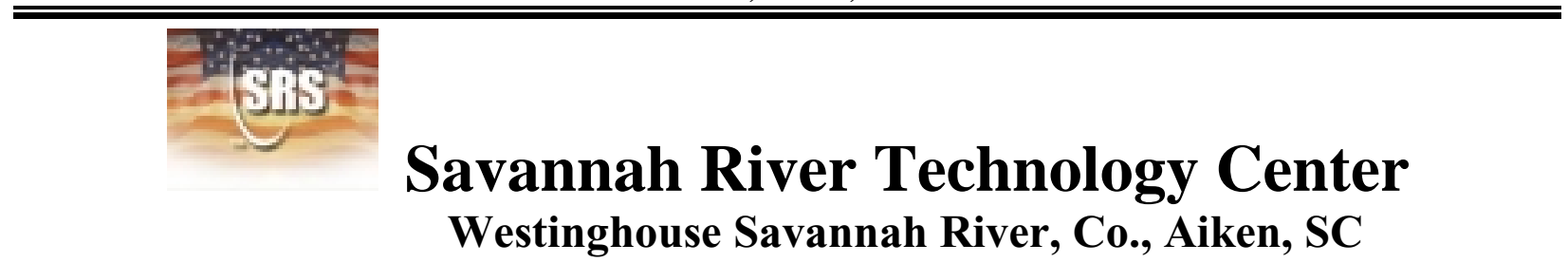




\section{DISCLAIMER}

This document was prepared as an account of work sponsored by an agency of the United States Government. Neither the United States Government nor the University of California nor any of their employees, makes any warranty, express or implied, or assumes any legal liability or responsibility for the accuracy, completeness, or usefulness of any information, apparatus, product, or process disclosed, or represents that its use would not infringe privately owned rights. Reference herein to any specific commercial product, process, or service by trade name, trademark, manufacturer, or otherwise, does not necessarily constitute or imply its endorsement, recommendation, or favoring by the United States Government or the University of California. The views and opinions of authors expressed herein do not necessarily state or reflect those of the United States Government or the University of California, and shall not be used for advertising or product endorsement purposes.

This is a preprint of a paper intended for publication in a journal or proceedings. Since changes may be made before publication, this preprint is made available with the understanding that it will not be cited or reproduced without the permission of the author.

This report has been reproduced directly from the best available copy.

Available electronically at http://www.doc.gov/bridge

Available for a processing fee to U.S. Department of Energy

And its contractors in paper from

U.S. Department of Energy

Office of Scientific and Technical Information

P.O. Box 62

Oak Ridge, TN 37831-0062

Telephone: (865) 576-8401

Facsimile: (865) 576-5728

E-mail: reports@adonis.osti.gov

Available for the sale to the public from

U.S. Department of Commerce

National Technical Information Service

5285 Port Royal Road

Springfield, VA 22161

Telephone: (800) 553-6847

Facsimile: (703) 605-6900

E-mail: orders@ntis.fedworld.gov

Online ordering: http:/ / www.ntis.gov/ordering.htm

\section{OR}

Lawrence Livermore National Laboratory

Technical Information Department's Digital Library

http: / / www.llnl.gov/tid/Library.html 


\title{
Final ROI Report - Technology Transfer of Waste-Reducing Groundwater Sampling Systems
}

\author{
Authors \\ Charles Noyes ${ }^{1}$ \\ Greg Howard ${ }^{1}$ \\ Dorothy Bishop ${ }^{1}$ \\ Cary Tuckfield ${ }^{2}$ \\ Robert Hiergesell ${ }^{2}$
}

September 30, 2002

${ }^{1}$ LLNL, Livermore, CA
${ }^{2}$ SRS, Aiken, SC 


\title{
Final ROI Report - Technology Transfer of Waste-Reducing Groundwater Sampling Systems
}

\author{
Charles Noyes*, Greg Howard*, Dorothy Bishop*, Cary Tuckfield**, Robert Hiergesell** \\ *Lawrence Livermore National Laboratory \\ ** U.S. Department of Energy Savannah River Site ${ }^{1}$
}

\section{Introduction}

This report presents the findings of a U.S. DOE Environmental Management technology transfer initiative of waste-reducing ground water sampling systems between Savannah River Site (SRS) and Lawrence Livermore National Laboratory (LLNL) which occurred during fiscal years 2001 and 2002. The report describes the collaboration between the two sites, the deployment of the Savannah River Site Purge Water Management System at LLNL, the changes made to that system for use at LLNL, and documents the return-on-investment derived from the system's use at LLNL as well as other benefits generated through this inter-laboratory collaboration. An evaluation of the deployment of the LLNL EasyPump sampling technology at SRS will be covered in a separate report from SRS.

\section{Background}

\section{Ground water sampling}

Traditional groundwater sampling methods generate up to three to four well volumes per sampling event. Regulatory requirements mandate management of purge water as a hazardous waste. In an effort to reduce monitoring costs, LLNL and SRS have each developed sampling systems that result in minimizing or eliminating purge water which can be costly to treat, especially if it contains mixed wastes. The Purge Water Management System (PWMS) developed at SRS is a closed-loop, non contact system used to return purge water back to the originating aquifer after a sampling event without significantly altering water quality. The EasyPump, a sampling technology developed at LLNL, is designed to collect a specific depth sample within a well while avoiding the collection of purge water and it's associated costs.

\section{Previous collaborations}

Collaborations which were started in the early '90s with LLNL's CES algorithm (a statistical approach to reduce the required sampling frequency of monitor wells) and SRS's well redundancy approach (a geostatistical tool to close out wells producing redundant information) led to the current collaboration involving sampling devices. SRS requested LLNL to sign a letter of intent to use their purge water management system under development with EM-50 funds. During that development period, 2 PWMS units were installed at LLNL with the agreement that data would be collected using the PWMS and other devices in current use at LLNL to compare data by the different methods and evaluate whether the data from samples generated by the different sampling methods produced similar results. Also during this development period, a 
joint proposal was submitted to the EM-Pollution Prevention Program to pay for the testing and transfer of two sampling technologies (the PWMS developed at SRS and the EasyPump developed at LLNL) as well as the drilling of a monitor well at LLNL that would be designed specifically for evaluating PWMS.

\section{Project Goals}

The primary objective of the study was to evaluate the application of these two wastereducing ground water sampling systems outside of the settings in which they were developed, namely, 1) the deployment of the PWMS system at LLNL, and 2) the deployment of the EasyPump at SRS (covered in a separate report). Three additional goals of the study were to: a) quantify the return-on-investment derived from reducing costly hazardous wastes generated as a by-product of environmental ground water sampling, b) confirm that the analytic results derived from the two systems were consistent with results obtained using standard sampling methods, and c) to determine whether modifications were needed to adapt these technologies for more universal application.

At LLNL, the project consisted of two separate phases. In phase 1, a new monitor well would be drilled and installed at the LLNL Livermore Site, designed specifically for evaluating the PWMS. In phase 2, four additional tankless PWMS systems would be installed for testing in pre-existing monitor wells at both the Livermore Site and Site 300.

\section{Project History}

\section{PWMS monitor well installation}

PWMS monitor well W-1701 was drilled and installed during July 2001. The drilling location is in a Zone 7 right-of -way, on the north side of Arroyo Seco. The well is positioned to monitor an offsite contaminant plume that has been targeted for cleanup. Drilling was performed using a rotary mud rig to a depth of 180 feet. Well completion and well specification data for W1701 are presented in Table 1. Following the standard LLNL final well development, well hydraulic testing, and baseline sampling procedures, quarterly sampling was initiated using the EasyPump. It had been agreed that 6 quarters of data would be collected by the EasyPump method so a data history could be established before switching to the PWMS. It is planned to switch to the PWMS in the spring of '03 after which 6 quarters of sampling data will be collected and compared to the EasyPump method to establish whether or not the two methods produced comparable data.

\section{Original PWMS systems}

Concurrent with the design, siting, and completion of W-1701, the two tankless PWMS units that had been originally installed at the LLNL Livermore Site in June 2000 were undergoing evaluation and testing. Based on that evaluation, several LLNL design changes were performed in order to 1) simplify the design to overcome a number of technical obstacles, such as dedicating expensive pumps to each well and accommodating the Christy Box completion of one of the wells, and 2) to minimize the cost of the unit as our RFP to the manufacturer came back at approximately $\$ 8 \mathrm{~K}$ instead of the $\$ 2.5 \mathrm{~K}$ estimated by $\mathrm{SRS}$ in the original proposal. With the 
redesigns incorporated into the unit, our technicians and engineers were able to reduce the costs to about \$2.5 per unit, providing they ordered the parts and did most of the assembly themselves.

\section{Redesign details}

The redesign of the PWMS system was undertaken by Greg Howard of the Environmental Restoration Division (LLNL/ERD) in three separate phases with discussion and consensus of our SRS collaborators. The initial LLNL redesign was initiated as a modification to one of the original units installed at $\mathrm{W}-1118$. The redesign was necessary to simplify the operation and maintenance of the system when installed in a below-grade Christy Box well-head completion. The dedicated control box (priced at approximately \$3700) was eliminated and the well-head assembly was simplified, and a mechanical flow meter, or rotometer, was substituted for the more expensive digital flow meter included in the original design ( $\$ 60$ vs. $\$ 600)$. In addition, quick-disconnect and other low cost fittings were used with the original packer and pump. A second full LLNL redesign was initiated to reduce the $\$ 8000$ purchase price cost to about $\$ 2500$. This redesign replaced the original PWMS unit with an internal "sleeve" consisting of 2 inch ID PVC Trilock casing, a low-cost packer, the rotometer, air supply line and top plate as dedicated equipment at each instrumented well. The redesign included the use of a dedicated pump at each well. The fully redesigned down-hole packer system (\$300 vs. \$1900) is readily removable and repairable by technicians in the field. The third LLNL design is similar to redesign \#2 but allows for the use of a non-dedicated portable pump, further reducing the per unit price to approximately $\$ 600$, not including labor necessary to assemble each unit. All told, we estimate that the total cost of the redesigned dedicated PWMS system has been reduced from about $\$ 8000$ to approximately $\$ 2370$ per location.

\section{LLNL deployment of modified PWMS systems}

Between December 2001 and September 2002, a total of four of the redesigned tankless PWMS systems were installed in three LLNL Livermore Site monitor wells and in one LLNL Site 300 monitor well. The wells selected include W-1225, W-1117, W-607, and NC7-67. The monitor wells were picked based on their hydrogeologic setting and their ability to pass the well screening criteria established at SRS by Robert Hiergesell. These screening criteria ensure that the retention time of the purge water from a prior sampling event does not exceed the length of time interval between sampling events. The hydrogeologic settings in which the systems were installed include a) areas with "mixed waste" contaminant plumes with a history of elevated tritium activities and VOC concentrations (W-1117 and W-1225) and b) areas in which elevated tritium activities predominate (W-NC7-67, and W-607). In both of these hydrogeologic settings, LLNL waste management procedures require that any purge water collected be treated as low level mixed hazardous waste. A summary description of each system, the nature of its redesign, and the date of deployment is presented in Table 2. As discussed above, a fifth modified PWMS system will be installed in PWMS well W-1701 in spring, 2003.

\section{Results}

\section{Cost-benefit analysis}

According to hazardous waste management policy currently in place at LLNL, the elevated tritium activities and VOC concentrations in wells W-1225,W-1117, W-607, and NC7-67 are 
considered low level hazardous mixed waste. The hazardous waste cost for disposal of this type of hazardous material is estimated to be about $\$ 222$ per gallon. Given a volume of 87 gallons for a 3 well volume purge at W-1225, we estimate that the cost savings per sampling event using the redesigned PWMS system is about $\$ 19,500$ for hazardous waste charges alone. The total cost savings per sampling event for all four PWMS wells in the project is about $\$ 66,150$ for hazardous waste charges alone, or $\$ 264,600$ per year for four quarterly sampling events. Using a conservative ten-year life cycle for the ground water monitoring network, this would result in a cost savings of $\$ 2.64 \mathrm{M}$ for these four wells alone. A cost savings matrix of the deployment of PWMS at LLNL, including both hazardous waste costs and PWMS redesign savings, is presented in Table 3.

\section{Other Benefits}

In addition to the return-on-investment benefits discussed above, other benefits accrued during the inter lab collaboration include: a) design improvements to the PWMS system have significantly decreased purchase price as well as operation and maintenance costs; b) proposed design improvements to the EasyPump should allow for better operation and sample collection (see SRS report); c) redesign aspects of the PWMS system have facilitated the testing and fielding of an LLNL "well within a well" multiple-screen monitor well system now being used at the Livermore $\mathrm{Site}^{2}$; and d) future proposed collaborative efforts to further improve and decrease the cost of environmental sampling and waste management within the DOE complex, including organizing a technical session on sampling methods at the next DOE TIE meeting hosted by LLNL/LBL in November of 2002.

\section{Project completion and expense report}

The final expenses for the LLNL portion of the project as of September 2002 are $\$ 95 \mathrm{~K}$. The final breakdown for expenditures is listed below. Although the project is complete as far as design, testing and installation of the sampling devices, sampling and analysis will continue using both systems until we have completed the evaluation and comparison of the EasyPump and PWMS devices. Those sampling and evaluation expenses incurred after the end of FY'02 will be included in the site's restoration effort.

Final Project Costs

\begin{tabular}{|l|c|}
\hline Drilling, completing and testing well & $\$ 45 \mathrm{~K}$ \\
\hline Sampling and analysis to date & $\$ 7 \mathrm{~K}$ \\
\hline Supplies \& parts to build units, & $\$ 8.5 \mathrm{~K}$ \\
\hline Design and labor costs & $\$ 15 \mathrm{~K}$ \\
\hline Installation of units & $\$ 5.5 \mathrm{~K}$ \\
\hline Additional sampling & $\$ 4.5 \mathrm{~K}$ \\
\hline Data evaluation & $\$ 6 \mathrm{~K}$ \\
\hline Report writing, meetings, and field visits & $\$ 3.5 \mathrm{~K}$ \\
\hline Total costs & $\$ 95 \mathrm{~K}$ \\
\hline
\end{tabular}




\section{Conclusions and Recommendations}

\section{Project summary:}

The dedicated PWMS monitor well, W-1701, has been drilled, completed, tested, and is undergoing quarterly sampling by the EasyPump method (to be continued for 6 quarters before installing the PWMS per agreement). The original tankless PWMS units that have been undergoing testing at the LLNL Livermore Site since June 2000 were redesigned to reduce purchase price cost as well as operation and maintenance costs with discussion and consensus of our SRS collaborators. A patent is pending on the redesign of the modified tankless PWMS units deployed at LLNL. To date, the total cost of the redesigned dedicated PWMS system used at LLNL has been reduced from about $\$ 8000$ to approximately $\$ 2370$ per location. The two teams of collaborators from SRS and LLNL continue to discuss and agree on design modifications of both the PWMS and EasyPump (deployed at SRS) to accommodate site specific criteria and cost considerations. Four of the modified PWMS systems have been installed this past year at the Livermore Site and Site 300 making a total of six PWMS units that have been installed during the past two years. An additional PWMS unit will be deployed in the spring of 2003 following the required six quarter sampling period of Well W-1701. Sampling and analysis will continue using both waste-reducing ground water sampling systems until we have completed the evaluation and comparison of the EasyPump and the modified PWMS devices. Initial data analysis indicates that the analytic results of samples collected using the modified PWMS systems at LLNL are consistent with analytic results collected using standard ground water sampling methods. A return-on-investment analysis indicates that the total cost savings per sampling event for all four PWMS wells in the project is about $\$ 66,150$ for hazardous waste charges alone, or about $\$ 264,600$ per year for four quarterly sampling events. Using a conservative ten-year life cycle for the ground water monitoring network, this would result in a cost savings of $\$ 2.64 \mathrm{M}$ for these four wells alone.

\section{Future plans}

The SRTC and LLNL team is preparing to organize a technical session on sampling methods at the next DOE TIE meeting hosted by LLNL/LBL. Scientists from SRTC and LLNL will lead this session where we will focus on comparing various sampling devices and processes currently in use by DOE for monitoring wells and preparing a table that illustrates appropriate field criteria when each system is best used. Cost information for each system will also be provided.

\section{Footnotes:}

1. Please note that no discussion of the use of the EasyPump at SRS is present in this report. A forthcoming report from SRS will cover this aspect of the initiative.

2. An innovative monitor well design which relies on the EasyPump for ground water sampling, is now being fielded at LLNL. Referred to as a "well within a well" design, the system allows for the sampling and monitoring of ground water from at least two separate well screens within a single well, potentially reducing monitor well costs by about $50 \%$. 


\section{Tables}

Table 1. PWMS monitor well W-1701 well specifications

Table 2. LLNL PWMS status and installation schedule

Table 3. Cost savings matrix for deployment of PWMS at LLNL

\section{Appendices}

A. Midterm LLNL report

B. Technology Transfer of Waste-Reducing Ground Water Sampling Systems proposal 


\section{Tables}


Table 1. LLNL PWMS Monitor Well W-1701 Well Specifications.

\begin{tabular}{cccccccc}
\hline \hline $\begin{array}{c}\text { Well } \\
\text { Name }\end{array}$ & Location & $\begin{array}{c}\text { Hydrostratigraphic } \\
\text { Unit } \\
\text { (HSU) }\end{array}$ & $\begin{array}{c}\text { Borehole } \\
\text { Depth } \\
(\mathrm{ft})\end{array}$ & $\begin{array}{c}\text { Casing } \\
\text { Diameter } \\
\text { (in) }\end{array}$ & $\begin{array}{c}\text { Screened } \\
\text { Interval } \\
(\mathrm{ft} \text { bgs) }\end{array}$ & $\begin{array}{c}\text { Sand Pack } \\
\text { Interval } \\
(\mathrm{ft} \text { bgs) }\end{array}$ & $\begin{array}{c}\text { Estimated } \\
\text { Sustainable } \\
\text { Yield (gpm) }\end{array}$ \\
\hline W-1701 & Offsite, & HSU 2 & 185 & 5 & $140-155$ & $136-156$ & 15 \\
& & & & $165-175$ & $163-181$ & \\
& $\begin{array}{c}\text { Treatment } \\
\text { Facility A } \\
\text { Area }\end{array}$ & & & & & & \\
& & & & & & & \\
& & & & & & & \\
\hline \hline
\end{tabular}

Table 2. Purge Water Management System Status and Installation Schedule at LLNL.

\begin{tabular}{|c|c|c|c|c|c|}
\hline Well Name & $\begin{array}{l}\text { Installation } \\
\text { Date }\end{array}$ & $\begin{array}{l}\text { Planned } \\
\text { Date }\end{array}$ & $\begin{array}{l}\text { Approximate } \\
\text { Cost }\end{array}$ & Description & Remarks \\
\hline W-356 & $\begin{array}{l}\text { June, } \\
2000\end{array}$ & $\begin{array}{l}\text { June, } \\
2002\end{array}$ & $\$ 8,000.00$ & Original SRS System & $\begin{array}{l}\text { original SRS system will be } \\
\text { maintained as designed }\end{array}$ \\
\hline W-1118 & $\begin{array}{l}\text { June, } \\
2000\end{array}$ & $\begin{array}{l}\text { June, } \\
2002\end{array}$ & $\$ 2,300.00$ & redesign $\# 1^{*}$ & $\begin{array}{l}\text { heavily modified SRS } \\
\text { design with original packer }\end{array}$ \\
\hline W-1225 & $\begin{array}{l}\text { December, } \\
2001\end{array}$ & $\begin{array}{l}\text { May, } \\
2002\end{array}$ & $\$ 2,370.00$ & redesign \#2** & $\begin{array}{l}\text { full redesign incorporating } \\
\text { "sleeve" and dedicated } \\
\text { pump }\end{array}$ \\
\hline NC7-67 & $\begin{array}{l}\text { August, } \\
2002\end{array}$ & $\begin{array}{l}\text { July, } \\
2002\end{array}$ & $\$ 2,370.00$ & redesign\#2 & similar to W-1225 \\
\hline W-1117 & $\begin{array}{l}\text { September, } \\
2002\end{array}$ & $\begin{array}{l}\text { May, } \\
2002\end{array}$ & $\$ 2,370.00$ & redesign\#2 & similar to W-1225 \\
\hline W-607 & $\begin{array}{l}\text { August, } \\
2002\end{array}$ & $\begin{array}{l}\text { June, } \\
2002\end{array}$ & $\$ 600.00$ & redesign\# $3^{* * *}$ & $\begin{array}{l}\text { redesign \#2 using non- } \\
\text { dedicated, portable rediflo }\end{array}$ \\
\hline W-1701 & $\begin{array}{c}\text { To be } \\
\text { determined }\end{array}$ & $\begin{array}{l}\text { April, } \\
2003\end{array}$ & $\$ 600.00$ & $\begin{array}{l}\text { Dedicated PWMS well installed } \\
\text { July } 2001 \text { redesign\#3 will be } \\
\text { installed following } 6 \text { quarters of } \\
\text { routine sampling }\end{array}$ & similar to W-607 \\
\hline
\end{tabular}

Footnotes:

* $\quad$ Redesign \#1 - LLNL removed the dedicated control box (priced at approx $\$ 3,700$ ) used a rotometer and implemented quick disconnect and other low cost fittings to existing packer and pump.

** Redesign \#2 - LLNL design includes the use of 2' pvc casing, low-cost packer, rotometer, air supply line and top plate as dedicated equipment. Dedicated pump is optional, but is included at this well location.

*** Redesign \#3 - LLNL design includes 2' pvc TriLock casing, low-cost balloon packer and access for nondedicated, portable pump. 
Table 3A. Cost Savings Matrix for Deployment of PWMS at LLNL - Hazardous Waste Savings.

\begin{tabular}{cccccccccc}
\hline \hline $\begin{array}{c}\text { Well } \\
\text { name }\end{array}$ & $\begin{array}{c}\text { Casing id } \\
\text { (in) }\end{array}$ & $\begin{array}{c}\text { Available } \\
\text { water } \\
(\mathrm{ft})\end{array}$ & $\begin{array}{c}\text { Gallons } \\
\text { per } \\
\text { foot }\end{array}$ & $\begin{array}{c}\text { Casing } \\
\text { vol. } \\
\text { (gals) }\end{array}$ & $\begin{array}{c}3 \text { casing } \\
\text { vols } \\
(\text { gals })\end{array}$ & $\begin{array}{c}\text { Hazardous } \\
\text { Disposal Cost } \\
(\$ 222 / \text { gal) })^{*} \text { per } \\
\text { sampling event }\end{array}$ & $\begin{array}{c}\text { Annual Disposal } \\
\text { Cost (quarterly } \\
\text { sampling) }\end{array}$ & $\begin{array}{c}\text { Life Cycle Cost } \\
(10 \text { years) }\end{array}$ \\
\hline W-607 & 4.5 & 9.5 & 0.83 & 7.85 & 23.54 & $\$ 5,226.10$ & $\$ 20,904.41$ & $\$ 209,044.08$ \\
W-1117 & 4.5 & 22.6 & 0.83 & 18.67 & 56.00 & $\$ 12,432.62$ & $\$ 49,730.49$ & $\$ 497,304.86$ \\
W-1225 & 5 & 28.7 & 1.02 & 29.27 & 87.82 & $\$ 19,496.48$ & $\$ 77,985.94$ & $\$ 779,859.36$ \\
NC7-67 & 4.5 & 52.7 & 0.83 & 43.53 & 130.59 & $\$ 28,991.11$ & $\$ 115,964.45$ & $\$ 1,159,644.53$ \\
\end{tabular}

Notes: * 2001 Cost estimate of hazardous waste per gallon disposal cost from LLNL Hazardous Waste Management Division.

Table 3B. Cost Savings Matrix for Deployment of PWMS at LLNL - Redesign Savings.

\begin{tabular}{lccccc}
\hline \hline Well Name & $\begin{array}{c}\text { PWMS Cost } \\
\text { Based on RFP }\end{array}$ & $\begin{array}{c}\text { Design Modification } \\
\text { Costs }\end{array}$ & $\begin{array}{c}\text { PWMS Redesign } \\
\text { Version* }\end{array}$ & Cost of unit & Cost Savings \\
\hline W-1225 & $\$ 8,000.00$ & $\$ 5,000.00$ & redesign \#2 & $\$ 2,370.00$ & $\$ 630.00$ \\
W-1117 & $\$ 8,000.00$ & $\$ 5,000.00$ & redesign \#2 & $\$ 2,370.00$ & $\$ 630.00$ \\
NC7-67 & $\$ 8,000.00$ & $\$ 2,000.00$ & redesign \#2 & $\$ 2,370.00$ & $\$ 3,630.00$ \\
W-607 & $\$ 8,000.00$ & $\$ 2,000.00$ & redesign \#3 & $\$ 600.00$ & $\$ 5,400.00$ \\
W-1701 & $\$ 8,000.00$ & $\$ 1,000.00$ & redesign \#3 & $\$ 600.00$ & $\$ 6,400.00$ \\
Total & $\$ 40,000.00$ & $\$ 15,000.00$ & & $\$ 8,310.00$ & $\$ 16,690.00$ \\
\hline \hline
\end{tabular}

Notes: * See Table 2 and report text for explanation of PWMS redesigns. 


\section{Appendix A}




\section{Midyear 2002 Interim Report: Technology Transfer of Waste-Reducing Groundwater Sampling Systems}

\section{Introduction}

Traditional groundwater sampling methods generate up to three to four well volumes per sampling event. Regulatory requirements mandate management of purge water as a hazardous waste. In an effort to reduce monitoring costs, LLNL and SRS have each developed sampling systems that result in minimizing or eliminating purge water which can be costly to treat, especially if it contains mixed wastes. The Purge Water Management System (PWMS) developed at SRS is a closed-loop, non contact system used to return purge water back to the originating aquifer after a sampling event without significantly altering water quality. The EasyPump units developed and deployed at LLNL eliminates purge water and consists of a power supply, control panel, pump, and bailors, which contain components of pump, check valve, and bladder.

Collaborations which were started in the early '90s with LLNL's CES algorithm ( a statistical approach to reduce the required sampling frequency of monitor wells) and SRS's well redundancy approach (a geostatistical tool to close out wells producing redundant information) led to the current collaboration involving sampling devices. SRS requested LLNL to sign a letter of intent to use their purge water management system under development with EM-50 funds. During that development period, 2 PWMS units were installed at LLNL, with the agreement that data would be collected using the PWMS and other devices in current use at LLNL to compare data by the different methods and evaluate whether the data from samples generated by the different sampling methods produced similar results. Also during this development period a joint proposal was submitted to the EM-Pollution Prevention Program to pay for the testing and transfer of two sampling technologies (the PWMS developed at SRS) and (the EasyPump developed at LLNL) as well as the drilling of a well at LLNL that would be cited in an area of where three bore volumes of purge water was required before sampling, in order to fully utilize the cost savings of the PWMS's design to return purge water to the originating aquifer.

\section{Project History}

Funding for the project was received toward the end of the first quarter of fiscal year ' 01 . LLNL hydrologists met to discuss and cite the well for the project and the designated well was added to the drilling priority list. Following the completion of wells drilled to make near term milestones, the drilling of well W-1701 was completed during the early summer of ' 01 . The drilling location is in a Zone 7 right-of -way, on the north side of Arroyo Seco. The drilling was performed by a rotary mud rig to a depth of 180 feet; the drilling diameter was 5" ID. At LLNL we are not required to perform 3 well volume purges of the borehole before sampling at all locations, but we were strongly urged to follow this process at the offsite wells, so it made sense to install this well to be used by the PWMS at this location. Following required well pump testing and completion scenarios, quarterly sampling was initiated with the EasyPump. It had been agreed that 6 quarters of data would be collected by the EasyPump method so a data history 
could be established before switching to the PWMS. It is planned to switch to the PWMS in the spring of '03 after which 6 quarters of sampling data will be collected and compared to the EasyPump method to establish whether the two methods produced comparable data.

Meanwhile the two PWMS units that had been installed at LLNL were undergoing evaluation and several design changes were performed in order to 1) simplify the design to overcome a number of technical obstacles such as dedicating expensive pumps to each well and accommodating the Christy box around the well head, and 2) to minimize the cost of the unit as our RFP to the manufacturer came back at $\sim \$ 8 \mathrm{~K}$ instead of the $\sim \$ 2.5 \mathrm{~K}$ estimated by SRS in the original proposal. With the redesigns incorporated into the unit, our technicians and engineers were able to reduce the costs to $\sim \$ 2.5$ per unit providing they ordered the parts and did most of the assembly themselves. Specific details of the design appear below.

\section{Redesign details}

Greg Howard of Environmental Restoration Division (LLNL/ERD) redesigned the Purge Water Management System (PWMS) for reduce the cost and accommodate specific site requirements at the Livermore Site. The redesigned system has been deployed in monitor well $\mathrm{W}-1225$, located in an area containing high concentrations of VOCs as well as elevated activities of Tritium. Modifications to the system include:

a) Eliminating the need for a dedicated control box at each location, including the use of a portable mechanical float flow meter instead of a digital flow meter (\$60 vs. \$600) and simplification of the well-head assembly by replacing costly fittings with inexpensive quickdisconnect fittings that achieve the same purpose. (\$3,700 savings from original design).

b) Greg then fully redesigned the down-hole packer system ( $\$ 300$ vs. \$1900), enabling technicians to readily pull and repair pumps installed in these locations or to use a portable pump system if appropriate. All told, we estimate that the total cost of the redesigned dedicated PWMS system has been reduced from about $\$ 8000$ to approximately $\$ 2370$ per location.

Due to the elevated tritium activities and VOC concentrations in the well, W-1225 is considered to contain mixed low level waste. The hazardous waste cost for disposal of this material is estimated to be about $\$ 222$ per gallon. Given a volume of 95 gallons for a 3 well volume purge at W-1225, we estimate that the cost savings per sampling event using the redesigned PWMS system is about $\$ 21,090$ per sampling event for hazardous waste charges alone.

\section{Project summary to date:}

- The required well has been drilled, completed, tested, and is undergoing quarterly sampling by the EasyPump method (to be continued for 6 quarters before installing the PWMS per agreement).

- The two teams of collaborators from SRS and LLNL have met 3 times to discuss and agree on design modifications of both the PWMS and EasyPump (deployed at SRS) to accommodate site specific criteria and cost considerations. The redesign has now been completed and the units are being assembled and prepared for installation. A table 
appears in the appendix of this report that shows the expected installation date of each unit at LLNL.

- Ongoing quarterly sampling is occurring in the two PWMS units already installed at LLNL and data is being evaluated by both methods.

\section{Future plans}

- The SRTC and LLNL team is preparing to organize a technical session on sampling methods at the next DOE TIE meeting hosted by LLNL/LBL. Scientists from SRTC and LLNL will lead this session where we will focus on comparing various sampling devices and processes currently in use by DOE for monitoring wells and preparing a table that illustrates appropriate field criteria when each system is best used. Cost information for each system will also be provided.

\section{Project completion and expense report}

The approximate expenses as of May '02 are $\$ 80 \mathrm{~K}$. The breakdown for expenditures to date are listed in the table below and the projected costs for completing the project are listed separately. We plan that the project will be complete as far as design, testing and installation of the sampling devices, but sampling and analysis will continue using both systems until we have completed the evaluation and comparison of the EasyPump and PWMS devices. Those sampling and evaluation expenses incurred after the end of FY'02 will be included in the site's restoration effort. The project final report will be completed at the end of FY'02.

\section{Approximate costs to date}

\begin{tabular}{|l|l|}
\hline Drilling, completing and testing well & $\$ 45 \mathrm{~K}$ \\
\hline Sampling and analysis to date & $\$ 7 \mathrm{~K}$ \\
\hline Supplies \& parts to build units, & $\$ 8.5 \mathrm{~K}$ \\
\hline Design and labor costs & $\$ 15 \mathrm{~K}$ \\
\hline
\end{tabular}

\section{Projected costs to end of Project}

\begin{tabular}{|l|l|}
\hline Installation of units & $\$ 5.5 \mathrm{~K}$ \\
\hline Additional sampling & $\$ 4.5 \mathrm{~K}$ \\
\hline Data evaluation & $\$ 6 \mathrm{~K}$ \\
\hline Report writing & $\$ 3.5 \mathrm{~K}$ \\
\hline
\end{tabular}




\section{Appendix B}


United States Department of Energy

Office of Environmental Management Fact Sheet

\section{Technology Transfer of Waste-Reducing Groundwater Sampling Systems \\ Lawrence Livermore National Laboratory \\ \& Savannah River Site}
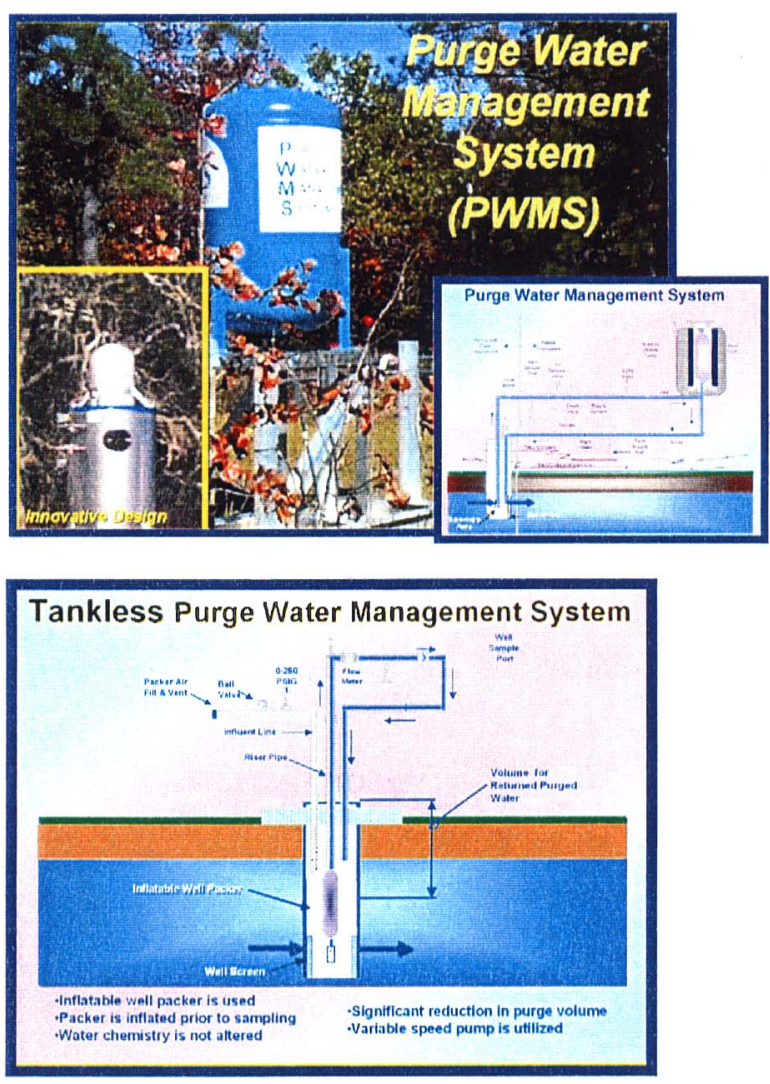

\begin{tabular}{|l|c|}
\hline DOE Monetary Benefits \\
\hline Requested Funds & $\$ 115,000$ \\
\hline Total Project Cost & $\$ 115,000$ \\
\hline Lifecycle Savings & $\$ 653,000$ \\
\hline Annual Savings & $\$ 133,000$ \\
\hline Return on Investment & $109 \%$ \\
\hline
\end{tabular}

\section{Benefits At-A-Glance}

- Reduces environmental, safety, and health risks to workers during sampling and waste management activities.

- Reduces lifecycle cost of groundwater sampling.

- The proposed sampling methods generate $\square$ zero $\square$ waste.

\section{Existing Situation}

Traditional groundwater sampling methods generate up to three to five well volumes per sampling event. In the past, the waste water (purge water) was merely discarded on the ground adjacent to the sampled well. However, more stringent regulatory requirements now mandate management of purge water as a hazardous waste. Many DOE sites, such as the Savannah River Site (SRS) and Lawrence Livermore National Lab (LLNL), are searching for and developing solutions to the problem of generation and management of purge water.

\section{Proposed Change}

In a technology transfer initiative, two Purge Water Management System (PWMS) units developed at SRS with DOE Environmental Management (EM)-50 funds will be deployed at LLNL. The PWMS is a closed-loop, noncontact system used to return purge water back to the originating aquifer after a sampling event without significantly altering water quality.

In addition Additionally, ten Low Volume Grab Sampling Systems (Easy Pump Units) developed at LLNL will be deployed at SRS.

This sampling technology eliminates purge water and consists of a power supply, control panel, pump, and bailors (which contain components of a tube with a pump, a check valve, and a bladder).

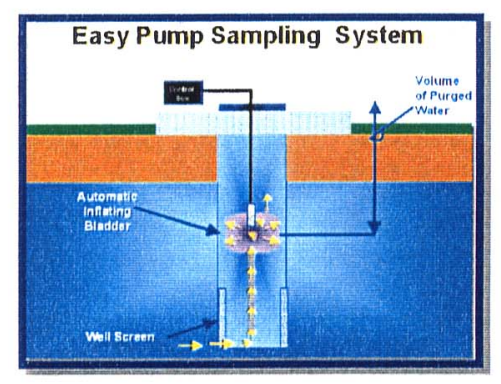

\section{Value of Improvement}

Both technologies have been in development and deployment for several years at their respective sites. Exchange of these technologies affords the opportunity to refine cost-effective solutions for well sampling and gives additional options to regulators and stakeholders at all DOE sites. In addition to providing a safer and more costeffective method for sampling wells, implementation of these two technologies will minimize waste generation and associated waste management costs. Each method is approaching a $\square$ zero $\square$ waste generation sampling capability.

\begin{tabular}{|l|c|}
\hline Lifecycle Waste Reduction \\
\hline Life Cycle Waste Reduction & $50 \mathrm{~m}^{3}$ \\
\hline Project Useful Life (Years) & 15 \\
\hline
\end{tabular}




\section{Technology Transfer of Waste-Reducing Groundwater Sampling Systems} Lawrence Livermore National Laboratory \& Savannah River Site

\section{Summary Data}

ROI Priority Area:

ROI Proposal ID No:

ROI Project Type:

Requested Funds:

Total Project Cost:

Projected Lifecycle Savings:

Implementing Group:

Benefiting Group:

Useful Life Years:

Return On Investment:

Projected Lifecycle Waste Reduction:

Project Contact:

Phone:

Email:
Environmental Restoration Projects

SR-2000-63 \& SR-2000-0064

Source Reduction

$\$ 115,000$

$\$ 115,000$

$\$ 653,000$ (Estimated Value)

EM

EM

15

$109 \%$

$50 \mathrm{~m}^{3}$

Clarence Beardsley

(803) 952-6726

clarence.beardsley@srs.gov 